\author{
Alina Walenia \\ University of Rzeszów \\ Department of Economic Policy \\ Institute of Economics and Finance \\ e-mail: alinawalenia@poczta.onet.pl
}

\title{
Systemowe metody monitorowania jakości pracy w urzędach administracji publicznej
}

\section{Systems methods of monitoring the quality of work in public administration offices}

Implementing modern methods of quality management improves the services provided by public administration. Quality management systems are tools for changing the structure, methods of operation, and consequently, the image of Polish administration. These systems are a modern method aimed at improving the management and quality of the public services provided. Implementing the system of solutions based on the ISO 9001 standard that ensures quality requires customers' needs to continually be improved, defined and fulfilled effectively and economically. Such activities in public administration offices make it possible to develop transparent, ordered, self-improving organisations that are open to customers' and employees' needs. The system of quality management ensures the functioning of offices in accordance with the rules of law, objectivity, and professional ethics. The purpose of this article is to assess the impact of systems methods of quality management in the public sector on the effectiveness and efficiency of the services provided, including the principles of professional ethics.

Keywords: public administration, management, quality systems, officer's ethics

JEL Classification: A13, M14 


\section{Wprowadzenie}

Wdrażanie nowoczesnych metod zarządzania jakością wpływa na poprawę usług świadczonych przez administrację publiczną. Systemy zarządzania jakością stanowią narzędzie zmiany struktury, sposobów działania i w konsekwencji wizerunku polskiej administracji. Systemy te stanowią nowoczesną metodę mającą na celu doskonalenie zarządzania, poprawę jakości świadczonych usług publicznych. Wdrażanie systemu rozwiązań zapewniających jakość, opartego na normie ISO 9001, zobowiązuje do ciągłego doskonalenia, definiowania potrzeb interesantów oraz ich realizowania w sposób efektywny i ekonomiczny. Działania takie w urzędach administracji publicznej stwarzają możliwość budowy przejrzystych, uporządkowanych, samodoskonalących się organizacji otwartych na potrzeby klientów i pracowników. System zarządzania jakością zapewnia funkcjonowanie urzędów zgodnie z zasadami praworządności, obiektywności i etyki zawodowej. Celem niniejszej publikacji jest ocena wpływu systemowych metod zarządzania jakością w sektorze publicznym na efektywność i sprawność świadczonych usług, z uwzględnieniem zasad etyki zawodowej.

Urzędy administracji publicznej to instytucje użyteczności publicznej. Podstawą ich działania jest służba społeczności lokalnej poprzez zaspokojenie jej potrzeb i uwzględnienie słusznych interesów ${ }^{1}$. Urzędy administracji samorządowej, wykorzystując środki budżetowe, świadczą usługi dla społeczności lokalnych, realizując zadania własne i zlecone z zakresu administracji rządowej. Dlatego też dla efektywnego wykorzystania środków budżetowych i zasobów, a przede wszystkim w celu realizacji podstawowej misji urzędu, jaką jest zaspokojenie potrzeb społeczności lokalnej, urząd administracji samorządowej powinien podjąć działania projakościowe. Wdrażanie systemu jakości usprawnia funkcjonowanie organizacji sektora publicznego. Konieczność ta podyktowana jest szczególnie zaufaniem obywateli. Jakość w administracji zdefiniowana jest jako przywództwo oparte na określeniu wizji i strategii urzędu. Jakość to sprawne zarządzanie i skoncentrowanie uwagi ma wymaganiach klientów. To także zidentyfikowane procesy i wskaźniki, zarządzanie usługami administracyjnymi, a nie sprawami, zarządzanie projektami, zadaniami strategicznymi i celami. Jakość to sprawny obieg informacji oraz efektywna kontrola wewnętrzna.

Współczesne pojmowanie jakości oparte na spełnianiu potrzeb i oczekiwań klientów dotyczy nie tylko świadczonych usług, ale także organizacji pracy w urzędzie i zarządzania nim. Dotychczasowy model administracji opartej na biurokratycznej racjonalności został w większości krajów europejskich zanegowany i zastąpiony przez model menedżerskiego zarządzania publicznego. Menedżerski system zarządzania charakteryzuje się m.in. tym, że administracja jest zorientowana na obywatela. Ma on na celu podporządkowanie działań oczekiwaniom obywateli. Jednostki administracji samorządowej wykonują zadania po

\footnotetext{
${ }^{1}$ Obwieszczenie Marszałka Sejmu Rzeczypospolitej Polskiej z dnia 20 grudnia 2019 r. w sprawie ogłoszenia jednolitego tekstu ustawy - Kodeks postępowania administracyjnego (Dz.U. 2020, poz. 256).
} 
skrajnie różnych kosztach i w różnym zakresie, dlatego też konieczne było wprowadzenie standardów usług publicznych wraz z systemem wskaźników i metodami pomiaru stopnia realizacji ustalonego standardu oraz stałe nadzorowanie, czy ustalony standard jest zachowany i czy wówczas organizacja potrafi skutecznie reagować (Izdebski \& Wrzosek, 2009, s. 124-125). System zarządzania jakością oparty na wymaganiach normy ISO 9001:2000 pozwala organizacjom publicznym odejść od sztywnego strukturalnego kierowania poszczególnymi komórkami na rzecz zarządzania procesami wdrażanymi w organizacji. Podejście takie umożliwia dostosowanie działania organizacji do wymagań klientów, a tym samym uzyskania „wartości dodanej” do tradycyjnych administracyjnych czynności. Wartości dodane w urzędzie publicznym stanowią zadowolenie obywateli ze sposobu ich obsługiwania przy zwykłych czynnościach administracyjnych oraz poprawa jakości świadczonych usług publicznych. Przestrzeganie ustalonych procedur w ramach systemu zarządzania jakością zapewnia funkcjonowanie urzędów zgodnie z zasadami etyki zawodowej. Zagrożeniem może być wzrost biurokratyzacji w urzędach, skupienie uwagi na dokumentowaniu czynności urzędniczych, a nie na sprawach, które są wnoszone przez strony do załatwienia. Nadmierne przeformalizowanie systemu może mieć wpływ na wydłużenie terminu świadczonych usług i wzrost kosztów administracyjnych z tym związanych.

Celem publikacji jest ocena znaczenia systemu wdrażania i zarządzania jakością opartą na normie ISO 9001:2000 w funkcjonowaniu urzędów sektora publicznego na przykładzie wybranych gmin Podkarpacia. W oparciu o literaturę przedmiotu przedstawione zostało podejście procesowe do zarządzania w administracji publicznej. Na podstawie badań ankietowych ${ }^{2}$ przeprowadzonych w wybranych jednostkach samorządu terytorialnego w województwie podkarpackim wyszczególnione zostały czynniki warunkujące proces wdrażania systemów jakości w urzędach administracji samorządowej. Badania ankietowe na wybranej grupie respondentów ${ }^{3}$ korzystających $\mathrm{z}$ usług publicznych umożliwiły dokonanie oceny wpływu wdrażanych systemów zarządzania jakością na jakość i terminowość świadczenia usług przez urzędy administracji samorządowej w województwie podkarpackim.

\section{Zarządzanie poprzez jakość w administracji publicznej}

Funkcja usługowa administracji w warunkach rosnącej globalizacji i wzmożonej konkurencji rynkowej staje się kluczowa dla zapewnienia warunków sprawnego funkcjonowania gospodarki i społeczeństwa - działalności firm i życia ludzi. Dlatego też niezbędne jest spojrzenie na działanie urzędów i instytucji publicz-

\footnotetext{
2 Badania ankietowe przeprowadzone zostały w 2017 r. wśród 40 pracowników samorządowych związanych z wdrażaniem systemów jakości w wybranych losowo 20 samorządach gmin w woj. podkarpackim. Badaniu ankietowemu poddano 20 wójtów/burmistrzów gmin z woj. podkarpackiego.

3 Badania ankietowe przeprowadzone w 2017 r. wśród wybranych losowo 40 osób korzystających z usług ankietowanych jednostek samorządowych w woj. podkarpackim.
} 
nych przez pryzmat procesów, a nie procedur. Tylko wówczas można będzie przejść od załatwiania spraw do świadczenia usług obywatelom (Bugdol, 2011, s. 170). Zastosowanie podejścia procesowego jest podstawą do wdrożenia budżetu zadaniowego i oceny efektywności oraz skuteczności usług administracyjnych. Określenie procesów zarządzania jakością jest podstawą do wdrożenia elektronicznego obiegu dokumentów i innych systemów informatycznych oraz budowy e-administracji.

Problematyka zarządzania jakością w administracji publicznej jest szczególnie istotna w polityce Unii Europejskiej, wdrażającej zasady spójności we współpracy z państwami członkowskimi. Krajowe instytucje i organy odpowiadają za ustanowienie strategii wydatkowania i wybór projektów oraz dokonywanie płatności na podstawie wniosków złożonych przez beneficjentów. Ważnym zadaniem UE i państw członkowskich jest budowa sprawnego układu instytucjonalnego odpowiedzialnego za realizację polityki spójności, związanego z zarządzaniem programami operacyjnymi oraz realizacją projektów współfinansowanych z budżetu UE (Klamut, 2010, s. 45-48). Do zadań państwa członkowskiego należy ustalenie kompetencji instytucji oraz czynników warunkujących proces zarządzania w administracji. Kolejnym zadaniem jest podnoszenie jakości potencjału administracyjnego systemu instytucjonalnego, realizującego Umowę Partnerstwa ${ }^{4}$. Jakość w administracji publicznej, w tym także samorządowej, to sprawne zarządzanie. Pełna ocena działania instytucji publicznej może być dokonana tylko w sytuacji, kiedy można odnieść liczbę i jakość wyników do założonych rezultatów, tj. tego, czego oczekują obywatele od administracji, do tego, co ona dostarcza. W jednostkach samorządowych wdrażających systemy jakości sposoby świadczenia i oceny usług publicznych dokonywane przez instytucjonalny system nadzoru, jak i oceny opinii publicznej wskazywały na pozytywne przykłady w tym zakresie. Wdrażanie systemu zarządzania jakością $\mathrm{w}$ administracji jest metodą nowoczesną i doskonalącą. Wyszczególnionych zostało osiem podstawowych zasad doskonałości w zarządzaniu, mających istotny wpływ na proces wdrażania jakości w administracji publicznej (Piekara, 2010, s. 76-77), co prezentuje Rysunek 1.

Wskazując na normy ISO jako systemy zapewniające jakość, należy przypomnieć ich podstawową typologię:

(1) ISO 9000:2005 Quality Management System - podstawy systemów zarządzania jakością, terminologia,

(2) ISO 9001:2000 Quality Management System - wymagania dla systemu zarządzania jakością,

(3) ISO 9004:2000 Quality Management System - wytyczne dotyczące doskonalenia systemu jakości i całej organizacji,

(4) ISO 19011:2002 Guidelines on Quality - wytyczne dotyczące auditowania systemów zarządzania jakością i/lub zarządzania środowiskowego,

\footnotetext{
${ }^{4}$ Umowa Partnerstwa jest dokumentem określającym kierunki interwencji w latach 2014-2020 trzech polityk unijnych w Polsce - Polityki Spójności, Wspólnej Polityki Rolnej i Wspólnej Polityki Rybołówstwa. Jest to dokument zatwierdzony przez Komisję Europejską.
} 
(5) ISO 1401:2004 Environmental Management Systems - General quidelines on principes system and supporting technics - wytyczne dotyczące ustanowienia, wdrożenia i utrzymania systemu zarządzania środowiskowego.

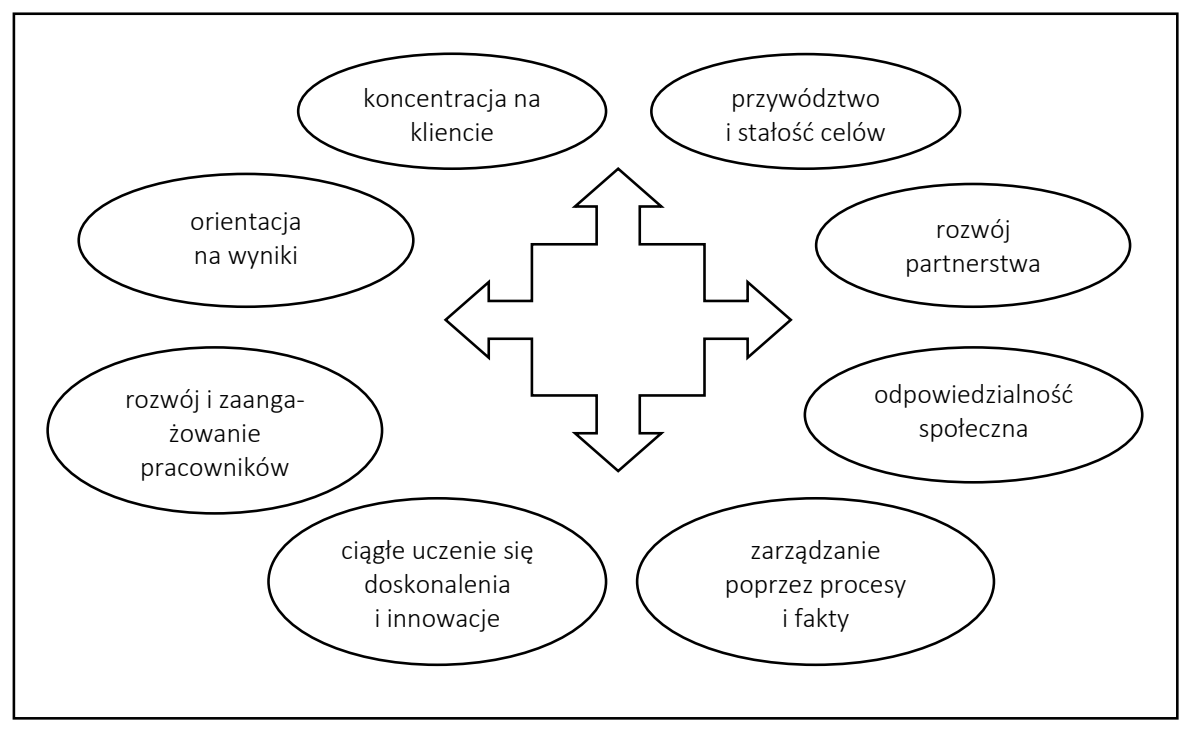

Rysunek 1. Zasady doskonałości w zarządzaniu w administracji

Źródło: opracowanie własne

Wdrożenie systemu rozwiązań zapewniających jakość opartą na normie ISO 9001:2000 zobowiązuje do ciągłego doskonalenia, definiowania potrzeb interesantów oraz ich realizowania w sposób efektywny i ekonomiczny. Takie działania w urzędach administracji publicznej stwarzają możliwości budowy przejrzystych, uporządkowanych i samodoskonalących się organizacji otwartych na potrzeby klientów i pracowników.

$\mathrm{Na}$ poziomie funkcjonowania administracji realizowana musi być konstytucyjna zasada ,państwa prawa”, w związku z tym coraz bardziej pożądane staje się stosowanie systemów zarządzania jakością. Pojęcie systemu jakości oznacza uwzględnienie takich elementów, jak: środki i przedmioty pracy, metody, technologie, pracownicy i wzajemne relacje pomiędzy tymi elementami. Norma ISO 9001:2000 definiuje system jako: strukturę organizacyjną, rozłożenie odpowiedzialności, procedury, procesy i zasoby umożliwiające zarządzanie jakością. Natomiast zapewnienie jakości to wszystkie zaplanowane i systematyczne działania, które są niezbędne do uzyskania i utrzymywania odpowiedniego stopnia wiarygodności, że wyrób lub usługa będzie spełniać ustalone wymagania jakościowe. Wymagania normy ISO 9001:2000 mają na celu zapewnienie w organizacji: powtarzalności postępowania, planowania działań projakościowych, ustalenia spo- 
sobu dokumentowania poszczególnych czynności. Wszystkie te działania odnoszą się do zapobiegania, a nie naprawiania.

Stosowanie systemów zarządzania jakością według norm ISO w administracji publicznej było historycznie najwcześniejsze i popularne już w latach 80., szczególnie w europejskiej administracji samorządowej. Spowodowane było to wcześniejszą popularnością modelu w sektorze prywatnym, wymiernością efektów jego stosowania w postaci certyfikatu oraz dążeniem do poprawy świadczonych usług w zorganizowany, planowy i powtarzalny sposób. Wspólne inicjatywy na rzecz zarządzania jakością w administracji publicznej krajów UE były podejmowane bardzo często na szczeblu spotkań dyrektorów generalnych administracji publicznej państw członkowskich. W Unii Europejskiej nie istnieje jednolita polityka w zakresie zarządzania jakością w administracji publicznej. Poszczególne kraje same ustalają zasady i szczegóły takiej polityki w ramach ogólnej misji i strategii administracji publicznej. Najczęściej stosowane koncepcje zarządzania to: zarządzanie przez określanie rezultatów, zarządzanie wynikami i zarządzanie jakością. Najczęściej używane w krajach UE narzędzia dotyczące zarządzania jakością to: audyty jakości, modele samooceny, pomiary wyników, standardy obsługi, narzędzia benchmarkingu, zestawy rekomendowanych procedur. W celu przyspieszenia procesu zmiany i dokonania poprawy usług publicznych w urzędach administracji publicznej podejmowane są następujące działania:

(1) koncentracja na rozwoju potencjału ludzkiego poprzez programy szkoleniowe na temat zarządzania jakością,

(2) budowanie sieci współpracy jednostek administracji w celu tworzenia forum dla wymiany poglądów i interdyscyplinarnych grup roboczych,

(3) stosowanie nowych technologii informatycznych (e-administracja) dla wymiany wiedzy, informacji i najlepszych praktyk,

(4) ustanawianie nagród i wyróżnień w zakresie jakości dla uznawania wyróżniającej się jakości usług dla klientów.

W większości krajów UE inicjatywy w zakresie zarządzania jakością były wyraźnie związane z całościowymi programami modernizacji administracji. Były one formułowane na szczeblu centralnym poprzez np. programy poprawy produktywności i jakości w urzędach administracyjnych, opracowanie polityki jakości, planowanie wieloletniej modernizacji. Widoczne były dążenia do poprawy świadczenia usług na szczeblu lokalnym. Zjawiska te występowały głównie w krajach o zdecentralizowanej strukturze administracji i silnych tradycjach samorządności na szczeblu lokalnym.

System zarządzania jakością nie jest zbudowany tylko w oparciu o normę jakości. W praktyce organizacja, która nie korzysta z normy ISO, może posiadać lub budować własny system zarządzania jakością. Musi on uwzględniać fakt, że na jakość wpływają różne współzależne od siebie części, które można pogrupować w podsystemy. Ponadto system taki może być udokumentowany np. w postaci procedur, instrukcji lub nieudokumentowany, tj. utrwalony w wiedzy, narzędziach pracy (Hausner, 2008, s. 89-90). Urzędy, które nie wprowadziły systemów opartych o normy ISO, też posiadają systemy zarządzania. Działają zgodnie $\mathrm{z}$ instrukcjami kancelaryjnymi, ustawami i rozporządzeniami resortowymi. 
Ten zbiór zewnętrznych przepisów determinuje przebieg procesów realizowanych w urzędach. Nie tylko administracja państwowa jest zarządzana z zewnątrz, administracja samorządowa też nie jest samodzielna. Nie może sama zmieniać większości procesów obsługi klienta, działa w oparciu o obowiązujące procedury określone przepisami prawa.

System zarządzania jakością jest: zbiorem reguł, zasad i norm postępowania, narzędziem doskonalenia jakości, dynamiczną strukturą pozwalającą na uporządkowanie organizacji, gwarantem stabilnej jakości, dobrym narzędziem edukacji, podstawą wdrożenia filozofii $\mathrm{TQM}^{5}$. Podstawowym celem systemu zarządzania jakością jest rzetelnie wykonywana służba publiczna dla obywateli Rzeczpospolitej Polskiej. Realizowanie tego zadania w sposób sprawny, zgodnie z potrzebami społeczeństwa i oczekiwaną wysoką jakością usług wymaga wdrożenia i przestrzegania w administracji zasad etycznych. Etyka stanowi jeden z podstawowych elementów budowy pozytywnego wizerunku jednostki administracji publicznej, a tym samym wizerunku urzędnika. System zarządzania jakością nie zawsze gwarantuje wysoką jakość usług publicznych ani też sprawne zarządzanie całą organizacją. System ten identyfikowany jest z nadmiernym wzrostem biurokracji, przestrzeganiem określonych procedur w zakresie postępowania urzędnika wykonującego usługi publiczne.

\section{Funkcjonowanie systemu zarządzania jakością w administracji samorządowej - wyniki badań ankietowych}

System zarządzania jakością to skoordynowane działania związane z kierowaniem organizacją i jej nadzorowaniem w celu osiągania zakładanych efektów; zintegrowany jest z codzienną praktyką i innymi systemami. Wdrożenie systemu jakości ukierunkowane jest na zarządzanie poprzez planowanie celów jakościowych oraz sterowanie jakością, czyli określenie zadań, metod i środków umożliwiających jej egzekwowanie na poszczególnych etapach świadczenia usług (Władek, 2016, s. 124-125). Wyszczególnione zostały następujące etapy opracowania i wdrażania systemu zarządzania jakością:

(1) diagnoza systemu zarządzania jakością,

(2) organizacja projektu w zakresie zadań projakościowych,

(3) określenie celów wdrażania systemu,

(4) uruchomienie portalu informacyjnego wspierającego zarządzanie jakością,

(5) identyfikacja i opis procesów,

(6) szkolenia i stymulowanie zmiany postaw pracowników,

(7) wdrażanie systemu zarządzania jakością zgodnego z wymaganiami ISO 9001.

\footnotetext{
${ }^{5}$ Total Quality Management - kompleksowe zarządzanie przez jakość w administracji publicznej.
} 
Zadania w zakresie opracowywania, wprowadzania i stosowania systemu zarządzania jakością wykonuje kierownik jednostki sektora finansów publicznych. Do jego obowiązków należą m.in. opracowanie, wdrożenie i stosowanie polityki jakości w sposób przejrzysty, zrozumiały, stanowiący integralną część polityki jakości urzędu. Istotnym zadaniem pozostaje zapewnienie środków finansowych na realizację celów jakościowych w systemie, a także opracowanie i opublikowanie dokumentów systemowych.

Certyfikat jakości jest świadectwem dokumentującym zdolność urzędu do zapewniania odpowiedniego poziomu jakości świadczonych usług. W większości urzędów administracji samorządowej zakończony został proces wdrażania znormalizowanych systemów zarządzania jakością zamiast istniejących, niedoskonałych systemów jakości. Wymagania normy ISO 9001:2000 wprowadziły zmiany m.in. w zakresie planowania działań, odpowiedzialności oraz obsługi klienta.

W literaturze wyszczególnionych zostało dziesięć podstawowych zasad służby publicznej wykorzystanych do oceny systemu jakości. Są to:

(1) wyznaczanie standardów usług - jasno sprecyzowanych, monitorowanych i dostępnych publicznie,

(2) otwartość i zapewnienie pełnej informacji o danej usłudze, jej koszcie i przewidywanych rezultatach,

(3) konsultowanie i włączanie obecnych i potencjalnych odbiorców usług publicznych oraz wykorzystywanie ich opinii do dokonywania usprawnień,

(4) dostępność usług dla wszystkich potencjalnych odbiorców i zapewnienie możliwości wyboru, o ile jest to możliwe,

(5) traktowanie wszystkich odbiorców w ten sam sposób - respektowanie ich prywatności i godności, okazywanie pomocy i uprzejmości,

(6) korygowanie popełnianych błędów szybko i efektywnie, posiadanie jasnej, upowszechnionej, łatwej w stosowaniu procedury składania skarg i zażaleń,

(7) efektywne wykorzystywanie środków dla zapewnienia najlepszej wartości dla podatników i odbiorców,

(8) wdrażanie innowacji i usprawnień w zakresie usług publicznych,

(9) współpraca z innymi dostawcami dla zapewnienia, że usługi są efektywne,

(10) zapewnienie satysfakcji użytkownika z jakości otrzymywanych usług.

Głównym celem polityki jakości w analizowanych urzędach jednostek samorządu terytorialnego jest tworzenie przyjaznego klimatu i odpowiednich warunków dla realizacji zbiorowych potrzeb wspólnoty m.in. poprzez załatwianie spraw w trybie i terminach określonych w przepisach prawa. Zadaniem kierownictwa urzędu jest także uwzględnianie potrzeb i oczekiwań społeczności lokalnej w programach i planach rozwojowych jednostki samorządowej. Z zasad etyki urzędniczej wynika, że obowiązkiem jest nawiązywanie relacji z klientami na zasadach partnerskich z zachowaniem służebności urzędu wobec wspólnoty lokalnej. 
Wyniki badań ankietowych ${ }^{6}$ (Rysunek 2) wskazały, że wdrożony system zarządzania jakością wywierał pozytywny wpływ m.in. na optymalizację i standaryzację procesów decyzyjnych, poprawę poziomu kontroli i zarządzania, efektywne wykorzystanie zasobów i większą ochronę przed odpowiedzialnością prawną (mniejsza liczba pomyłek i błędów). Najważniejsze efekty wynikające z funkcjonowania systemu zarządzania jakością w urzędzie to m.in.: poprawa jakości usług publicznych, przestrzeganie zasad etyki urzędniczej, poprawa wizerunku urzędu, a także wzrost poziomu satysfakcji mieszkańców wspólnoty samorządowej.

Wyniki badań ankietowych potwierdzały pozytywne zmiany oraz poprawę sprawności funkcjonowania urzędów. System zarządzania jakością promuje administrację uwzględniającą potrzeby obywateli, co znajduje odzwierciedlenie w ograniczonej liczbie skarg kierowanych do urzędów, a dotyczących jakości i terminowości świadczonych usług publicznych. Wdrażanie tego systemu weryfikuje stosowanie podstawowych zasad postępowania administracyjnego, tj. obiektywizmu i praworządności. Tylko $10 \%$ badanych urzędów nie dostrzegało zależności pomiędzy wprowadzeniem systemu zarządzania jakością a poprawą świadczonych usług publicznych. Nie określiło kierunków dalszego doskonalenia i zmian projakościowych w urzędach. Zdecydowana mniejszość ankietowanych wskazywała, że system zarządzania jakością powoduje nadmierną biurokrację związaną z dokumentowaniem wykonywanych usług publicznych.

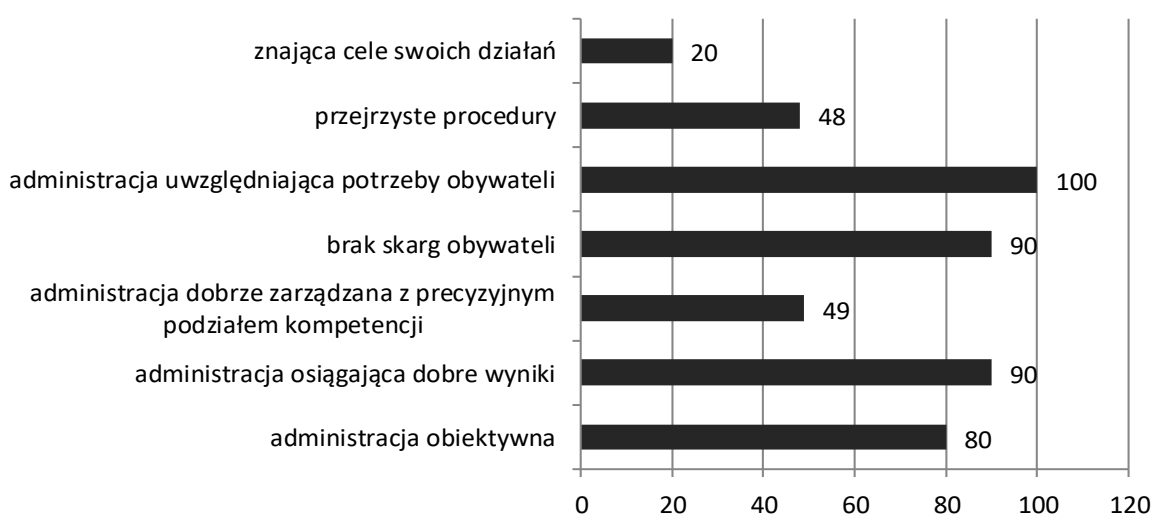

Rysunek 2. Korzyści wynikające z wdrożonego systemu zarządzania jakością w ankietowanych jednostkach samorządowych woj. podkarpackiego

Źródło: opracowanie własne na podstawie badań ankietowych

\footnotetext{
${ }^{6}$ Ankieta przeprowadzona wśród wójtów/burmistrzów wybranych 20 jednostek samorządu terytorialnego w woj. podkarpackim.
} 
Najczęściej podawane definicje jakości w administracji publicznej to:

(1) zespół cech usługi publicznej, spełniający wymogi odbiorcy,

(2) działanie na rzecz społeczeństwa zgodnie z prawem i w poczuciu uczciwości,

(3) wynik dobrej pracy,

(4) osiągnięcie optymalnej relacji pomiędzy efektem zadaniowym a kosztem jego uzyskania,

(5) określenie opisujące poziom wykonania usługi,

(6) zbiór norm określających wymagania,

(7) pojęcie opisujące realizację celu z punktu widzenia oczekiwań odbiorcy,

(8) sprawne i efektywne świadczenie usług, terminowość, właściwa organizacja, standard wykonania, wysoki poziom usług.

Sprawnie działająca administracja zapewnia zadowolenie obsługiwanych klientów, a poprzez to znajduje uznanie obywatela. Sprawność administracji oznaczającą właściwe i terminowe załatwianie spraw umożliwiają przejrzysta struktura organizacyjna urzędu, jednoznaczny podział zadań i odpowiedzialności kompetentnych pracowników.

O jakości w administracji decydują głównie terminowość w załatwianiu spraw i struktura organizacyjna minimalizująca koszty działania. Najczęściej diagnozowane czynniki ograniczające wdrażanie systemów zarządzania jakością według ankietowanych pracowników samorządowych (Rysunek 3) to m.in.:

(1) brak motywacyjnego systemu wynagradzania urzędników w powiązaniu ze zwiększonym zakresem obowiązków wynikających z procedur systemu jakości,

(2) niski stan wiedzy pracowników na temat zarządzania jakością,

(3) niewłaściwa organizacja pracy urzędu, częste reorganizacje oraz zmiany struktury organizacyjnej i kompetencji urzędników,

(4) niewielki udział środków w budżecie jednostki samorządowej na szkolenia, szczególnie w zakresie jakości i zasad etyki urzędniczej,

(5) brak utożsamiania się pracowników z celami urzędu jako organizacji.

Ankietowani wskazywali, że w najmniejszym zakresie na wdrażanie systemu zarządzania jakością w urzędach wpływał brak motywacyjnego systemu wynagradzania urzędników w powiązaniu $\mathrm{z}$ dodatkowymi obowiązkami wynikającymi z procedur systemu jakości. Zdecydowana większość urzędników była skłonna do zaakceptowania dodatkowych obowiązków związanych $\mathrm{z}$ tym procesem w przekonaniu, że urząd, w którym pracują, będzie lepiej oceniany przez osoby z zewnątrz. Pracownicy urzędu utożsamiają proces wprowadzenia systemu zarządzania jakością z dodatkowymi nowymi obowiązkami powiązanymi ze wzrostem biurokracji. Procedury w ramach systemu jakości zobowiązują do sporządzania dodatkowych dokumentów. Istotną barierą we wdrażaniu systemu zarządzania jakością były ograniczone wydatki na szkolenia z zakresu nowoczesnych metod zarządzania, w szczególności dotyczących organizacji pracy i zasad etyki urzędniczej. 


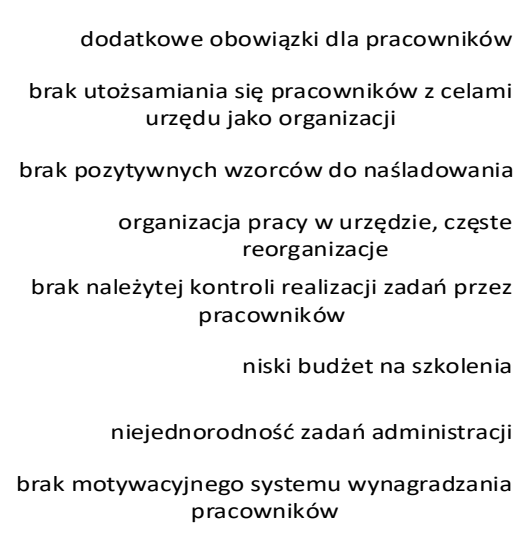
pracowników

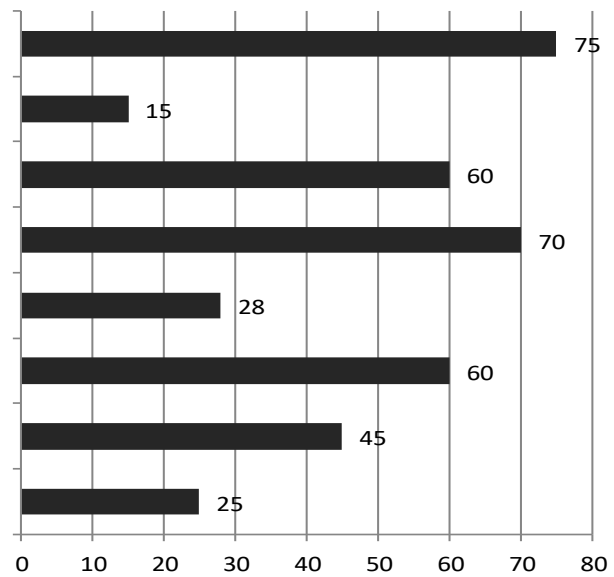

Rysunek 3. Bariery utrudniające wdrażanie systemu zarządzania jakością w ankietowanych jednostkach samorządu terytorialnego woj. podkarpackiego

Źródło: opracowanie własne na podstawie badań ankietowych

Wyniki badań przeprowadzonych na wybranej grupie interesariuszy urzędów (Rysunek 4) wykazały, że po wdrożeniu systemu zarządzania jakością osiągane były wymierne efekty, tj. nastąpiła poprawa funkcjonowania urzędów na wszystkich szczeblach zarządzania. Ankietowani klienci urzędów wskazywali, że widoczne były efekty związane $\mathrm{z}$ funkcjonowaniem systemu zarządzania jakością. Zjawisko to wpływało na wzrost zadowolenia obsługiwanych osób, poprawę kompetencji i wiedzy pracowników, skuteczność ich działania, zdyscyplinowanie. Respondenci wskazywali głównie, że wdrożony system ogranicza zjawisko „wpływu polityki” w urzędach oraz przekłada się na właściwe i terminowe załatwianie spraw. System zarządzania jakością zobowiązał urząd do utworzenia przejrzystej struktury organizacyjnej, jednoznacznego rozdziału kompetencji wśród pracowników, co czyni administrację przyjazną dla obywatela. Wdrażane zasady systemu jakości przyczyniają się do przestrzegania zasad etyki zawodowej urzędnika samorządowego.

Rozwiązania z zakresu zarządzania jakością stanowią integralną część systemu zarządzania administracją, mającą na celu poprawę efektywności, skuteczności działania urzędów, a także zarządzania zasobami ludzkimi i wzrost zadowolenia klienta. Zmiany związane $\mathrm{z}$ ich wprowadzaniem wpływają na poprawę organizacji i efektywności działania administracji publicznej, w tym samorządowej. Czynnikiem sprzyjającym poprawie jakości administracji samorządowej jest wypracowany model służby cywilnej i procesy integracji z Unią Europejską. Wprowadzone metody zarządzania jakością powinny być przyjazne dla pracowników urzędu, klientów i nie powinny powodować wzrostu biurokracji. Integralnym elementem wszystkich systemów zarządzania jakością jest dokumentacja (specyfikacje, procedury). Nadrzędnym celem wdrażania systemu zarządzania jakością 
W administracji publicznej jest certyfikacja, zwiększenie zadowolenia klienta z usług mu świadczonych oraz zwiększenie efektywności wykorzystania środków publicznych. Wartością dodaną jest zbudowanie projakościowej kultury organizacyjnej, a także likwidowanie usterek i nieprawidłowości w działaniu systemu. Wdrażanie nowoczesnych metod zarządzania wpływa na poprawę jakości usług świadczonych przez polską administrację. Systemy zarządzania jakością stanowią narzędzie zmiany struktury, sposobów działania i w konsekwencji wizerunku polskiej administracji.

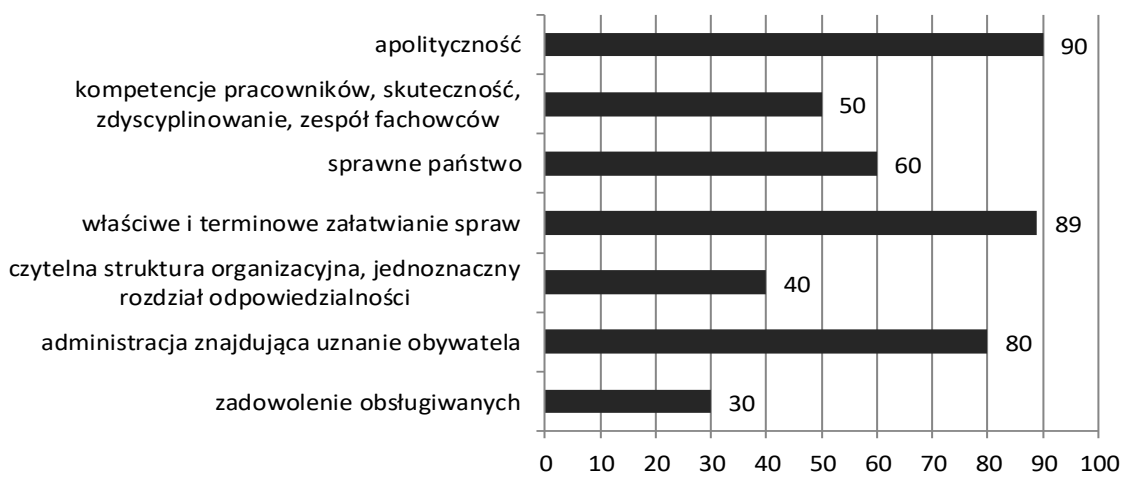

Rysunek 4. Ocena interesariuszy urzędu dotycząca funkcjonowania systemu zarządzania jakością w administracji samorządowej

Źródło: opracowania własne na podstawie badań ankietowych

Tryb postępowania, czyli metodyka wdrażania systemu zarządzania jakością w urzędach administracji samorządowej, rozpoczyna się od podjęcia decyzji o jego wprowadzeniu. Następną czynnością było poszukiwanie jednostki konsultingowej, która udzielała doradztwa przy budowie i wdrażaniu systemu jakości. Po podpisaniu umowy z firmą konsultingową wydawane było zarządzenie władz jednostki samorządowej o rozpoczęciu prac wdrożeniowych. Decyzję o przebiegu tego procesu poprzedzała analiza, z której sporządzany był raport zawierający ocenę organizacji urzędu, zalecenia, uwagi i opinie, które były uwzględnione podczas prac nad systemem. Następnie opracowywany był harmonogram wdrażania systemu jakości, określający etapy działania, dokonujący wyboru zespołów wdrożeniowych, audytów wewnętrznych i pełnomocnika ds. jakości i przeprowadzania szkoleń. Szkolenia obejmowały wszystkich pracowników, a ich przedmiotem było przekazanie najważniejszych informacji dotyczących wymagań modelu, definicji procesu, zasad identyfikowania, opisu, analizy i sposobów doskonalenia procesów. Kolejnym etapem, po szkoleniu, było uporządkowanie istniejącej i opracowanie nowej, wymaganej przez normę dokumentacji. Jest to okres identyfikowania, opisywania i doskonalenia oraz ustanowienia zasad nadzoru procesów. Każdy proces to zbiór określonych sposobów postępowania. Przygotowanie, realizacja i weryfikacja procesów miały na celu osiągnięcie założeń polityki jakości 
urzędu. Procesy stanowiły punkt wyjścia do określenia bardziej szczegółowych procedur i instrukcji działania, opisujących schemat postępowania podczas realizacji zadań. Dla ułatwienia prac powoływany był zespół wdrożeniowy, składający się z przedstawicieli kierownictwa i najważniejszych pracowników. Podstawowe zasady, które były stosowane, to (Pająk, 2006, s. 145-146):

(1) identyfikacja procesów uwzględniająca podstawowe zadania urzędu i sposoby ich realizacji,

(2) uporządkowanie procesów umożliwiające przedstawienie powiązań pomiędzy nimi, ich hierarchii z wyszczególnieniem procesów głównych, operacyjnych.

Procesy główne obejmują podstawowe zadania urzędu wynikające z przepisów obowiązującego prawa, natomiast procesy operacyjne stanowią elementy procesów głównych, bezpośrednio związanych z realizacją usług publicznych. W grupie procesów wspomagających wymienione zostały czynności zabezpieczające niezbędne zasoby i zarządzanie systemem jakości, pośrednio związane $\mathrm{z}$ realizacją usług (Batko, 2009, s. 150-154).

Procesy przedstawiane były w postaci diagramów postępowania (algorytmów) typu liniowego lub rozwiniętego. Diagramy przedstawiają wzajemne powiązania i następstwo czynności oraz ich przyporządkowanie realizatorom. Diagramy te poddaje się analizie dotyczącej poszczególnych czynności, która uwzględnia między innymi takie elementy, jak: sekwencja działań, osoby i komórki je realizujące, zasoby niezbędne do ich realizacji oraz liczba i usytuowanie punktów decyzyjnych. W skład dokumentacji opisującej funkcjonowanie procesów w urzędzie wchodzą:

(1) księga jakości,

(2) procedury wraz z wykorzystywanymi w nich formularzami: systemowe (wymagane przez normę), operacyjne (opis zasad realizacji postępowania),

(3) instrukcje,

(4) akty normatywne wewnętrzne, tj. stosowne uchwały rady, zarządzenia kierownika urzędu.

Zgodnie $\mathrm{z}$ wymaganiami normy konieczne jest ustalenie zasad nadzorowania dokumentacji urzędu. Procedury są wydawane zarządzeniem kierownika urzędu i podlegają ciągłym zmianom, w miarę jak zmieniają się okoliczności spraw i same sprawy. Najważniejszym zadaniem jest określenie mierników dla poszczególnych procesów i komórek organizacyjnych, pozwalających ustalić skuteczność realizowanych działań. Ustala się parametry poszczególnych procesów (usług) realizowanych w komórkach organizacyjnych, które należy mierzyć, grupując je w trzy obszary:

(1) produktowy - dotyczący głównych cech wykonywanych usług (stosunek liczby dobrych do złych),

(2) procesowy - dotyczący kontroli procesu realizacji usługi - mierniki wewnętrzne efektywności (czas realizacji, koszty, liczba spraw),

(3) satysfakcji - dotyczące reakcji klienta na usługi.

Mierniki te dotyczą trzech podstawowych kategorii: jakość, czas i koszty. Definicja mierników określa: efekt (na czym zależy klientowi), zużycie zasobów, 
cele organizacji (jakie są preferencje kierownictwa), realizację procesu (jakie są preferencje i cele wykonawcy). Standardy traktowane są jako zbiór wartości parametrów charakteryzujących daną usługę. Zwykle prezentowane są klientom urzędu w formie rozbudowanych wniosków lub kart zawierających podstawowe informacje na temat: sposobu, terminu i warunków realizacji spraw.

Wraz z wdrażaniem systemu jakości przeprowadza się reorganizację w urzędzie, zmianę struktury organizacyjnej i regulaminu oraz określa wartość i cele dla poszczególnych komórek, a następnie opracowuje się politykę jakości wraz z mierzalnymi celami jakościowymi, które podlegają ciągłym usprawnieniom. Po udokumentowaniu systemu zarządzania jakością w księdze jakości przystępuje się do przeprowadzenia audytów wewnętrznych i zewnętrznych, których celem jest sprawdzenie, czy urząd opracował i wdrożył wymagane normą dokumenty systemu. Podczas audytów dokonywana jest ocena zgodności realizowanych zadań z przepisami prawnymi i zasadami normy oraz przyjętymi do systemu procedurami. Audyty wewnętrzne przeprowadzane są przez przygotowanych pracowników urzędu, a w przypadku audytu przedcertyfikacyjnego system analizowany jest przez niezależnych audytorów jednostki konsultingowej. W razie stwierdzenia niezgodności podejmowane są działania korygujące, natomiast brak niezgodności podczas audytu przedcertyfikacyjnego upoważnia do wystąpienia o certyfikację. Wówczas dokonuje się wyboru jednostki upoważnionej do nadawania certyfikatów jakości, która przeprowadza audyt certyfikujący i potwierdza spełnienie wymagań normy przyznaniem certyfikatu. Certyfikat jakości jest świadectwem potwierdzającym zdolność urzędu do zapewnienia odpowiedniego poziomu jakości świadczonych usług (Batko, 2009, s. 134-136).

\section{Podsumowanie}

Zmiany w funkcjonowaniu administracji samorządowej w Polsce, w tym przede wszystkim konieczność wdrażania nowoczesnych metod zarządzania jakością usług publicznych (w tym konieczność ich monitorowania), wynikają z takich przesłanek, jak: globalizacja gospodarek, znaczący wzrost wykorzystania technologii przez społeczeństwa i organizacje, organizacyjna presja podwyższania efektywności, a także rosnąca świadomość konieczności orientacji na klienta-obywatela w świadczeniu usług publicznych. Menedżerowie w sektorze publicznym są obecnie pod stałą presją poprawy funkcjonowania swoich organizacji w obszarze zwiększania wydajności, skuteczności, terminowości oraz jakości usług. Tworzy się wręcz swoista kultura ciągłej poprawy instytucji publicznej, z wykorzystaniem metod i narzędzi zarządzania stosowanych w sektorze prywatnym. Do praktyki zarządzania w sektorze publicznym wkroczyła m.in. koncepcja poprawy jakości i monitorowania usług za pomocą różnych technik i wskaźników, która może wspomóc lokalne władze w doskonaleniu poziomu świadczonych usług. Zdiagnozowana ocena systemu zarządzania jakością w wybranych jednostkach samorządu terytorialnego woj. podkarpackiego wskazywała, że system opar- 
ty na wymaganiach normy ISO 9001-2000 pozwala na odejście od sztywnego kierowania poszczególnymi komórkami na rzecz zarządzania procesami, jakie są w organizacji realizowane. Podejście takie umożliwiało dostosowanie działalności urzędów do wymagań klientów, a tym samym wpływało na poprawę obsługi obywateli w wykonywaniu czynności administracyjnych. System zarządzania jakością zobowiązał urząd do utworzenia przejrzystej struktury organizacyjnej, jednoznacznego rozdziału zadań wśród pracowników, co uczyniło administrację przyjazną dla obywatela. System zarządzania jakością przyczynił się do przestrzegania zasad etyki zawodowej urzędnika samorządowego.

\section{Bibliografia}

Batko, R. (2009). Zarządzanie jakościa w urzędach gminy. Kraków: Wydawnictwo Uniwersytetu Jagiellońskiego.

Bugdol, M. (2011). Zarzadzanie jakościa w urzędach administracji publicznej. Teoria i praktyka. Warszawa: Wydawnictwo Difin.

Hausner, J. (2008). Zarzadzanie publiczne. Warszawa: Wydawnictwo Naukowe Scholar.

Izdebski, J. \& Wrzosek, S. (2009). Rola nauki administracji w identyfikowaniu patologii w organizacji i funkcjonowaniu administracji publicznej. W: P. J. Suwaj, D. R. Kijowski (red.), Patologie w administracji publicznej (s. 806-814). Warszawa: Wolters Kluwer.

Klamut, M. (2010). Uwarunkowania podnoszenia konkurencyjności regionów w Polsce. W: W. Kosiedowski (red.), Konkurencyjność gospodarcza regio$n u$ w warunkach nowego ustroju terytorialno-administracyjnego. Torun: Wydawnictwo Uniwersytetu Mikołaja Kopernika.

Obwieszczenie Marszałka Sejmu Rzeczypospolitej Polskiej z dnia 20 grudnia 2019 r. w sprawie ogłoszenia jednolitego tekstu ustawy - Kodeks postępowania administracyjnego. Dz.U. z 2020, poz. 256.

Piekara, A. (2010). Jakość administracji w Polsce. Zarys współczesnej problematyki. Warszawa: Wydawnictwo Uniwersytetu Warszawskiego.

Władek, Z. (2016). Organizacja $i$ zarzadzanie $w$ administracji publicznej. Zarys wykładu. Warszawa: Wydawnictwo Difin. 